\title{
Cytokine-Dependent Balance of Mitogenic Effects in Primary Human Lung Fibroblasts Related to Cyclic AMP Signaling and Phosphodiesterase 4 Inhibition
}

\author{
JENS SELIGE, ${ }^{*}$ HERMANN TENOR, ${ }^{2}$ ARMIN HATZELMANN, ${ }^{3}$ AND TORSTEN DUNKERN' \\ 'Department of In-Vitro Biology I, Nycomed GmbH, Konstanz, Germany \\ ${ }^{2}$ Department of In-Vitro Biology 2, Nycomed GmbH, Konstanz, Germany \\ ${ }^{3}$ Department of Biologics, Nycomed $\mathrm{GmbH}$, Konstanz, Germany
}

\begin{abstract}
Interleukin- / $\beta$ (IL-1 $\beta$ ) and basic fibroblast growth factor (bFGF) are important regulators of proliferation, and their expression is increased in lungs of patients with asthma, idiopathic pulmonary fibrosis (IPF), or chronic obstructive pulmonary disease (COPD). We investigated the effect of $I L-1 B$ and $b F G F$ on proliferation of human lung fibroblasts and the role of COX-2, PGE ${ }_{2}$, and cAMP in this process. Furthermore, the effect of phosphodiesterase (PDE) 3 and 4 inhibition was analyzed. In primary human lung fibroblasts low concentrations of $\mathrm{IL}-1 \beta(<10 \mathrm{pg} / \mathrm{ml})$ potentiated the bFGF-induced DNA synthesis, whereas higher concentrations revealed antiproliferative effects. Higher concentrations of IL-1 B-induced COX-2 mRNA and protein associated with an increase in PGE 2 and cAMP, and all of these parameters were potentiated by bFGF. The PDE4 inhibitor piclamilast concentration-dependently reduced proliferation by a partial GI arrest. The PDE3 inhibitor motapizone was inactive by itself but enhanced the effect of the PDE4 inhibitor. This study demonstrates that bFGF and IL- $1 B$ act in concert to fine-tune lung fibroblast proliferacion resulting in amplification or reduction. The antiproliferative effect of $I L-1 B$ is likely attributed to the induction of COX-2, which is further potentiated by bFGF, and the subsequent generation of $P G E_{2}$ and CAMP. Inhibition of PDE4 inhibizion (rather than PDE3) may diminish proliferation of human lung fibroblasts and therefore could be useful in the therapy of pathological remodeling in lung diseases.
\end{abstract}

Wound healing and scarring are essential physiological mechanisms to maintain tissue integrity and function. However, they can exaggerate to a profibrotic state or even fibrosis especially under repeated exposure to various insults such as virus/bacterial infections, chemicals, radiation, or allergens, which at the end can impair the function of the afflicted organs.

Fibrosis of different extent, localization and etiology in the lung accompanies various diseases and is often associated with inflammation such as in asthma, chronic obstructive pulmonary disease (COPD), and idiopathic pulmonary fibrosis (IPF). Peribronchiolar wall fibrosis is described in COPD patients (Spurzem and Rennard, 2005) and a fibrotic thickening of the basal membrane has also been observed in asthmatic patients. For asthma and COPD the impact of these fibrotic processes, which are most likely driven by repeated inflammation-repair cycles (Jeffery, 2001; Barnes, 2003), is not totally clear. However, in IPF the massive subpleural honeycombing parenchymal fibrosis and the fibrotic vascular remodeling are the major causes for reducing lung forced vital capacity (FVC), leading to a poor prognosis of this disease (Gross and Hunninghake, 200I). Thus, the 5-year mortality in IPF is higher than in many cancer types (American Thoracic Society, 2000).

Lung fibroblasts may cause fibrotic remodeling attributed to their potential to excessively proliferate and deposit matrix, representing one disease mechanism in pulmonary ailments. Taming hyperactivated lung fibroblasts may be critical for therapeutic success in IPF, a relentlessly progressing and devastating condition that remains rather poorly addressed by current treatment options. Activation of lung fibroblasts or recruited fibrocytes (Andersson-Sjoland et al., 2008) in IPF is driven by a myriad of growth factors, cytokines and chemokines, such as TGF- $\beta$, PDGF, basic fibroblast growth factor (bFGF), and interleukin-I $\beta$ (IL- I $\beta$ ? from various cellular sources (Agostini and Gurrieri, 2006). Several drug candidates such as neutralizing antibodies against TGF- $\beta$ or multi-specific cytokine receptor kinase inhibitors (previously developed for oncology indication) are in clinical development for IPF (Giri et al., 1993; Dempsey et al., 2006).

bFGF (Kranenburg et al., 2005) is a critical growth factor in fibrosis. As a potent elicitor of lung fibroblast proliferation, bFGF has been proposed to induce fibrogenic, proliferative effects on lung fibroblasts in IPF based on histological investigations in lung tissue from patient with IPF (Inoue et al., 2002). In COPD an up-regulation of bFGF-receptors has been described in bronchial airway walls (Kranenburg et al., 2005). Strikingly, by using explanted rat lung slices and primary pulmonary fibroblasts a recent study demonstrated that TGF- $\beta$ unfolds its proliferative activity on fibroblasts by stimulating their bFGF release that acts in an autocrine fashion (Khalil et al., 2005). Besides this activity, bFGF is supposed to contribute to vascularization of the parenchyma representing another disease mechanism in IPF (Strieter, 2005).

\begin{abstract}
Annotation: Data of this paper have been published in parts by the poster: "CAMP-dependent inhibition of bFGF and interleukin-I $\beta$ induced proliferation in primary human lung fibroblast," Keystone Asthma \& Fibrosis 2009. Authors: Jens Selige $1 *$. Hermann Tenor ${ }^{2}$, Armin Hatzelmann ${ }^{3}$ and Torsten Dunkern.
\end{abstract}

*Correspondence to: Jens Selige, Byk-Gulden Str.2, 78467

Konstanz, Germany. E-mail: jens.selige@nycomed.com

DOI: $10.1002 / j \mathrm{cp} .22037$ 
IL-I $\beta$ is expressed in alveolar macrophages of IPF patients with a constitutive interstitial inflammation (Zhang et al., 1993) In animal models overexpression of IL- $1 \beta$ in airway epithelium induces fibrosis, while a IL-I receptor antagonist inhibits lung fibrosis (Piguet et al., 1993; Kolb et al., 200I; Lappalainen et al., $2005)$. Lower concentrations of IL-I $\beta$ have been described to exert modest proliferative effects on cells such as human lung fibroblasts, aside from inducing the release of PDGF and collagen I (Goldring et al., 1988; Raines et al., 1989). In contrast, higher concentrations of $I L-1 / \beta$ have been reported to cause antiproliferative effects, for example, in endothelial cells (Cozzolino et al., 1990) and in cardiac fibroblast (Palmer et al., 1995).

Mechanistic interactions between bFGF and IL-I $\beta$ on proliferation of rat aortic smooth muscle cells (Bourcier et al., 1995) and on COX-2 expression in human osteosarcoma cells have been reported (Laulederkind et al., 2000). Because of the important roles of bFGF and IL-I $\beta$ in the progression of fibrotic processes in the lung, we analyzed the interplay between different concentrations of $\mathrm{IL}-\mathrm{I} \beta$ and $\mathrm{bFGF}$ on proliferation of primary human lung fibroblasts. The crucial regulatory role of COX-2, its product $P G E_{2}$ and the second messenger CAMP is elucidated and the mechanistic basis to interfere with cytokine-induced proliferation by means of inhibition of CAMP. hydrolyzing PDEs (such as PDE3 and PDE4) is analyzed. Previously, it was shown that CAMP and more specifically PDE4 inhibitors reduce a number of fibroblast functions such as fibronectin-induced chemotaxis, fibroblast-driven collagen-gel contraction, myofibroblast transition, proliferation and formation of extracellular matrix (Kohyama et al., 2002, 2004; Togo et al., 2008, 2009).

The results of the current study suggest that the interplay between bFGF and IL-I $\beta$ promotes lung fibroblast proliferation, which might also drive the fibrotic process in lungs of IPF patients. In addition, these studies also establish conditions under which PDE4 inhibitors become efficient, and might therefore be considered as therapeutic drugs for IPF and possibly other respiratory diseases associated with fibrosis.

\section{Materials and Methods Materials}

The selective PDE3 inhibitor motapizone (Borbe et al., 1986) was a generous gift from Sanofi-Aventis (formerly Rhone-Poulenc Rorer, Cologne, Germany). The PDE2 inhibitor 9-(6-phenyl-2-oxohex-3yl)-2-(3,4-dimethoxybenzyl)purin-6-one; example 100 from US patent 5861396 (Bayer AG), the selective PDE4 inhibitors piclamilast RP7340I (Benzamide, 3-cyclopentyloxy-4-methoxy-N(3,5-dichloro-4-pyridyl) (Raeburn et al., 1994), roflumilast $\mathrm{N}$-oxide (Hatzelmann and Schudt, 2001) and the PDE5 inhibitor sildenafil were synthesized at the chemical facilities of Nycomed $\mathrm{GmbH}$.

\section{Cell culture}

Normal human lung fibroblasts (NHLF, Cambrex Bio Science, Wakersville, MD) were cultured in Fibroblast Basal Medium plus FGM SingleQuots ${ }^{\text {B }}$ (both Lonza, Wakersville, MD) in tissue culture flasks at $37^{\circ} \mathrm{C}$ in an atmosphere containing $5 \% \mathrm{CO}_{2}$ up to the eight passage.

\section{RNA samples}

RNA samples from primary human lung fibroblasts were prepared according to the instructions of the manufacturer using the High Pure RNA isolation kit (Roche Applied Science, Mannheim Germany). RNA levels were quantified with the Nanodrop ND-1000 spectrophotometer (PEQLAB Biotechnologie GmbH, Erlangen, Germany) and then stored at $-80^{\circ} \mathrm{C}$.

\section{cDNA synthesis}

One microgram RNA was reverse-transcribed using random hexanucleotide primers (Roche Applied Science), dNTPs (PCR 3 Mix, Larova, Teltow, Germany) and avian myeloblastosis virus (AMV) reverse transcriptase (Roche Diagnostics GmbH, Penzberg Germany) at $42^{\circ} \mathrm{C}$ for $1 \mathrm{~h}$. CDNAs were diluted in $1 \mathrm{mM}$ Tris, $0.1 \mathrm{mM}$ EDTA, $\mathrm{pH} 8.0$, to a final concentration of $2 \mathrm{ng} / \mathrm{ml}$ and stored at $-20^{\circ} \mathrm{C}$ until further use.

\section{Quantitative real-time PCR}

All primers and 6-carboxyfluorescein (FAM)- or VIC-labeled probes were obtained from Applied Biosystems (Darmstadt, Germany). TaqMan gene expression assay HSO0153133_ml was used for specific detection of prostaglandin-endoperoxide synthase 2 and used the intronexon boundary 5-7. For normalization we used primers and VIC-labeled probes for detection of $18 \mathrm{~S}$ ribosomal RNA. The following endogenous $18 \mathrm{~S}$ rRNA control primers and probe were used: sense $5^{\prime}$-CGGCT. ACCACATCCAAGGAA-3', antisense 5'-GCTGGAATTACCGCGGCT-3', probe 5'-VIC-TGCTGGCACCAGACTTGCCCTCTAMRA-3'.

For analyzing the gene expression of PDE4 we used designed primer and probe sets as follows: PDE4A (NM_006202) sense, 5'. GTGGCTCCGGATGAGTTCTC-3', antisense, 5'-GGGCTGCTGTGGCTTACAG-3', probe 5'-FAM-CCGGGAGGAATTCGTGGT-minor groove binder-3' (MGB); PDE4B (NM_002600) sense, 5'-AGCAGCACAAAGACGCTTTGT-3', antisense, 5'-TCAGTCTCTCCCAGGGAATCTC-3' , probe $5^{\prime}$-FAM-TGATTGATCCAGAAAAC-MGB-3'; PDE4C (NM_000923) sense, 5'-ACTCTGGAGGAGGCAGAGGAA-3', antisense, 5'-AGGCAACTCCAAGGCCTCTT-3', probe 5' 'FAM-AAGAGACAGCTTTAGCC-MGB3'; PDE4D (NM_006203) sense, 5'-GGCAGGGTCAAACTGAGAAATT-3', antisense 5'-TGACTGCCACTGTCCTTTTCC-3', probe 5'-FAM-TAGAGGAAGATGGTGAGTCAG-MGB-3'. The PDE4 subtype primer/probe sets have been designed to bind at the $3^{\prime}$ end of the open reading frame of each subtype, at positions where individual splice variants of one subtype are identical.

For analyzing the gene expression of cyclin DI, cyclin EI, CDK6, and CDK2 we used the following TaqMan ${ }^{\mathbb{R}}$ gene expression assays from Applied Biosystems: Hs00277039_ml, Hs00233356_ml,

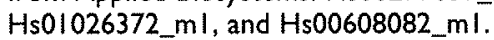

TaqMan PCRs were run on ABI 7900 HT Sequence Detection Systems (Applied Biosystems). Each PCR reaction was performed in a total volume of $25 \mu \mathrm{l}$ in 96-well plates, containing $2.5 \mu \mathrm{l}$ cDNA (5 ng), $12.5 \mu \mathrm{l}$ qPCR Mastermix Plus (Eurogentec, Seraing, Belgium), $1.25 \mu$ of the primer/probe set, and nuclease-free water. I8S rRNA primers and probe were used at a concentration of $50 \mathrm{nM}$ each. All PCRs were performed in triplicate for each sample. Relative expression units (REUs) were calculated from $\Delta C_{t}=C_{t_{F A M}}-C_{t_{V I C}}$ according to the equation $R E U=2^{\left(-\Delta C_{t}\right) \times 10^{7}}$ This REU unit describes the expression of a target RNA relative to the 18S rRNA internal standard of the respective sample (Herrmann et al., 2007).

By using plasmid DNA with PDE4 subtype-specific sequence inserts (PDE4 subtypes $A 4, A 10, B I, B 2, C l$ and D4 and D5) the specificity of the used PDE4 subtype-specific primer/probe sets was verified and identical amplification efficacy was shown.

Measurements of phosphodiesterase isoenzyme activities and preparation of cellular extracts

Cells $\left(1-3 \times 10^{6}\right)$ were washed twice in phosphate-buffered saline (PBS) and resuspended in I $\mathrm{ml}$ homogenization buffer $(137 \mathrm{mM}$

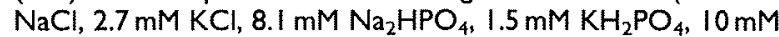
HEPES, I mM EGTA, I $\mathrm{mM} \mathrm{MgCl} 2$, I $\mathrm{mM} \beta$-mercaptoethanol, $5 \mathrm{mM}$ pepstatin $A, 10 \mathrm{mM}$ leupeptin, $50 \mathrm{mM}$ phenylmethyl-sulfonyl fluoride, $10 \mathrm{mM}$ soybean trypsin inhibitor, $2 \mathrm{mM}$ benzamidine, $\mathrm{pH}$ 8.2). Thereafter, cells were disrupted by sonification and PDE activity was assessed as described by Thompson et al. (1979) 
with some modifications (Bauer and Schwabe, 1980). The assay mixture (final volume $200 \mu \mathrm{l}$ ) contained: Tris $-\mathrm{HCl} 30 \mathrm{mM} ; \mathrm{pH} 7.4$, $\mathrm{MgCl}_{2} 5 \mathrm{mM}, 0.5 \mu \mathrm{M}$ of either cyclic AMP or cyclic GMP as substrate including $\left[{ }^{3} \mathrm{H}\right] \mathrm{CAMP}$ or $[3 \mathrm{H}] \mathrm{cGMP}, 0.1 \mathrm{mM}$ EGTA, PDE isoenzyme-specific activators and inhibitors as described and cellular lysates. Reactions were performed for $30 \mathrm{~min}$ at $37^{\circ} \mathrm{C}$ in 96-well plates and terminated by adding $50 \mu 10.2 \mathrm{M} \mathrm{HCl}$ per well. Assays were left on ice for $10 \mathrm{~min}$ and then $25 \mu \mathrm{g} 5^{t}$-nucleotidase (Crotalus atrox) was added. Following incubation for $10 \mathrm{~min}$ at $37^{\circ} \mathrm{C}$ assay mixtures were loaded onto QAE-Sephadex A25 columns and subsequently eluted with $30 \mathrm{mM}$ ammonium formiate $(\mathrm{pH}$ 6.0). Thereafter radioactivity in the eluate was measured. Results were corrected for blank values (measured in the presence of denatured protein) that were below $2 \%$ of total radioactivity. Cyclic AMP degradation did not exceed $25 \%$ of the amount of substrate added. The final DMSO concentration was $0.3 \%(\mathrm{v} / \mathrm{v})$ in all assays. Selective inhibitors and activators of PDE isoenzymes were used to determine activities of PDE families as described previously (Rabe et al., 1993) with modifications. Briefly, PDE4 was calculated as the difference of PDE activities at $0.5 \mu \mathrm{M}$ cyclic AMP in the presence and absence of I $\mu M$ piclamilast. The difference between piclamilast-inhibited cyclic AMP hydrolysis in the presence and absence of $10 \mu \mathrm{M}$ motapizone was defined as PDE3. The fraction of cyclic GMP $(0.5 \mu \mathrm{M})$ hydrolysis in the presence of $10 \mu \mathrm{M}$ motapizone that was inhibited by $100 \mathrm{nM}$ sildenafil reflected PDE5. At the concentrations used in the assay piclamilast ( $\mu \mathrm{M})$, motapizone $(10 \mu \mathrm{M})$, and sildenafil $(100 \mathrm{nM})$ completely blocked PDE4, PDE3, and PDE5 activities without interfering with activities from other PDE families.

PDEI was defined as the increment of cyclic AMP hydrolysis (in the presence of I $\mu$ M piclamilast and $10 \mu \mathrm{M}$ motapizone) or cyclic GMP hydrolysis induced by $1 \mathrm{mM} \mathrm{Ca}{ }^{2+}$ and $100 \mathrm{nM}$ calmodulin. The increase of cyclic AMP $(0.5 \mu \mathrm{M})$ degrading activity (in the presence of $1 \mathrm{mM}$ piclamilast and $10 \mathrm{mM}$ motapizone) induced by $5 \mu \mathrm{M}$ cyclic GMP represented PDE2. The PDE2 inhibitor ( $100 \mathrm{nM})$ completely inhibited this cyclic GMP-induced activity increment further verifying that this activity is PDE2.

\section{Western Blot}

Proteins of the samples were separated on a 10\% SDS polyacrylamide gel. Thereafter, proteins were blotted onto a nitrocellulose transfer membrane (Protran nitrocellulose transfer membrane (Schleicher \& Schuell Bioscience GmbH, Dassel, Germany), for 2-3h. Membranes were blocked for $2 \mathrm{~h}$ in $5 \%$ (w/v) milk powder in PBS containing $0.1 \%$ Tween-20 (PBT), incubated for $2 \mathrm{~h}$ with the primary antibody against COX-2 (1:1,000 dilution, Cayman Chemicals, Ann Arbor, MI), washed three times in PBT, and incubated for $\mathrm{I} h$ with a horseradish peroxidase-coupled secondary antibody ( $1: 10,000$ dilution, Jackson ImmunoResearch Laboratories, Inc., West Grove, PA). After final washing with PBT (three times for $10 \mathrm{~min}$ each) blots were developed by using a chemiluminescence detection system (Lumi Light Plus, Roche $\mathrm{GmbH}$, Mannheim, Germany) and a luminescent image analyzer. To control homogenous protein loading, blots were additionally hybridized with a primary anti-GAPDH (antibody; $1: 2,000$ dilution, Calbiochem ${ }^{\text {B }}$, Darmstadt, Germany).

The densitometric analyses of the blots were performed by using the AIDA image analyzer software. Each signal was normalized by the overall signal of the corresponding blot. Results are expressed as arbitrary units related to GAPDH (\%).

\section{CAMP and PGE 2 ELISA measurements}

$5 \times 10^{5}$ human lung fibroblasts were seeded in six-well plates and starved the day after for $24 \mathrm{~h}$. Thereafter, the cells were treated with bFGF (Sigma-Aldrich, Inc., Saint Louis, MI) and IL-I $\beta$ (R\&D Systems, Inc., Minneapolis, MN) as indicated for additional $24 \mathrm{~h}$ at $37^{\circ} \mathrm{C}$
For detection of $\mathrm{PGE}_{2}, 1 \mathrm{ml}$ medium was removed and stored at $-80^{\circ} \mathrm{C}$ until measurement with a PGE 2 ELISA (Assay Designs, Ann Harbor, MI) according to the manufacturers instructions.

Alternatively, for CAMP measurements treated adding $\mathrm{HCl}$ to a final concentration of $0.3 \mathrm{M}$ lysed cells and were stored at $-20^{\circ} \mathrm{C}$ For measurement, thawed samples were diluted $1: 2(\mathrm{v} / \mathrm{v})$ in $0.1 \mathrm{M}$ $\mathrm{HCl}$. cAMP was quantified by competitive ELISA as instructed by the manufacturer (Assay Designs).

$\left[{ }^{3} \mathrm{H}\right]$ thymidine incorporation and flow cytometric cell cycle analysis

$2 \times 10^{4} \mathrm{NHLF}$ cells were plated into 24 -well or $10^{5}$ cells into 6-well cell culture plates precoated with $30 \mu \mathrm{g} / \mathrm{ml}$ collagen (INAMED Biomaterials, Fremont, CA), $10 \mu \mathrm{g} / \mathrm{ml}$ fibronectin (from human plasma, Sigma-Aldrich, MO), $10 \mu \mathrm{g} / \mathrm{ml}$ bovine serum albumin (Sigma-Aldrich, Inc., Saint Louis, Ml) and incubated for $24 \mathrm{~h}$ by $37^{\circ} \mathrm{C}$. Thereafter, cells were starved for $24 \mathrm{~h}$ in serum-free Fibroblast Basal Medium. Following preincubation with piclamilast $(I \mu M)$, motapizone $(I \mu M)$, and $|L-| \beta(10-100 \mathrm{pg} / \mathrm{ml})(R \& D$ Systems, Wiesbaden, Germany) fibroblasts were stimulated with $10 \mathrm{ng} / \mathrm{ml}$ bFGF. For flow cytometric cell cycle analysis, the cells were trypsinated, washed twice in PBS, resuspended in $500 \mu \mathrm{lPBS}$, treated with RNase $(10 \mu \mathrm{g} / \mathrm{ml}$, RNase A, VWR International $\mathrm{GmbH}$, Darmstadt, Germany) and propidium iodide $(50 \mu \mathrm{g} / \mathrm{ml}$, Sigma-Aldrich, St. Louis) was added. Thereafter, samples were analyzed on a FACSCalibur (BD Bioscience, Heidelberg, Germany).

For DNA synthesis measurement [methyl- ${ }^{3} \mathrm{H}$ ] thymidine $(\mathrm{I} \mu \mathrm{Ci} /$ well) was added to the cells for the last $6 \mathrm{~h}$ of the incubation period. Culture supernatants were removed, adherent cells were washed twice in PBS and exposed to ice-cold $10 \%(w / v)$ trichloroacetic acid (TCA) for $30 \mathrm{~min}$. Thereafter, TCA was removed and the fixed cells dissolved in $0.2 \mathrm{~N} \mathrm{NaOH}$. DNA-incorporated radioactivity was counted and expressed as cpm per well (LS6500, Beckman Counter, Krefeld, Germany).

PDE inhibitors were dissolved from stock solutions as described above and the final DMSO concentration was $0.1 \%(v / v)$. Neither PDE inhibitors nor vehicle were affecting cell viability.

\section{Data analysis and software}

Data are presented as means $\pm S D$. For statistical analysis, one-way ANOVA (GraphPad Prism 5.0; GraphPad Prism Software, Inc., San Diego, CA) was used. The grubbs test was used to identify and remove outliers in the sample datasets. Densitometric analysis of immunoblots was performed with the Advanced Image Data Analyzer (AIDA 3.22; Raytest). The primer and probe sets for quantitative $P C R$ analysis were designed using Primer Express 2.0 (Applied Biosystems).

\section{Results}

Biphasic effects of IL-I $\beta$ on proliferation-interaction with bFGF and the role of CAMP

In a first series of experiments we investigated the combined effects of IL-I $\beta$ and bFGF on primary human lung fibroblast proliferation. For this purpose, cells were starved overnight in serum free medium, stimulated subsequently for $24 \mathrm{~h}$ with IL-I $\beta$ and bFGF at varying concentrations, and assessed for proliferation as measured by $\left[{ }^{3} \mathrm{H}\right]$ thymidine incorporation (Fig. IA,B).

As expected, bFGF strongly induced proliferation of lung fibroblast in a concentration-dependent manner and at $10 \mathrm{ng} / \mathrm{ml}$ induced maximum proliferation of $14.6 \pm 2.8$-fold of control (Fig. IA; $n=3$, mean $\pm S D$ ).

In contrast, treatment with IL-I $\beta$ up to concentrations of $10 \mathrm{pg} / \mathrm{ml}$ only slightly increased proliferation (maximum: 2.2-fold), whereas higher concentrations appeared even to decrease DNA synthesis. This observation suggests that at higher concentrations of the cytokine mechanisms opposing the mitogenic effects of IL-I $\beta$ may evolve. 

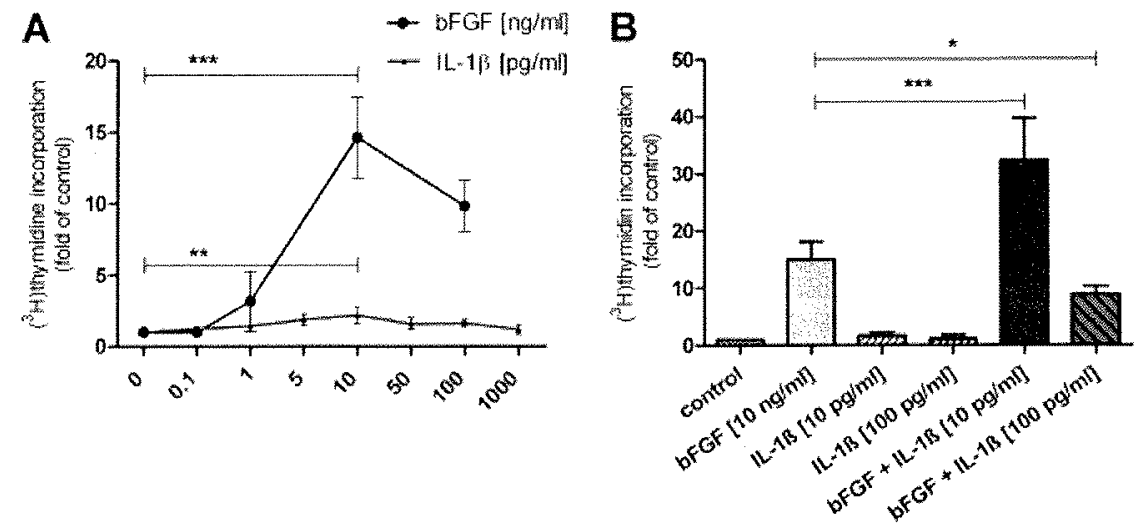

Fig. I. Effects of IL- $1 \beta$ and bFGF on proliferation of NHLF. A: NHLF were starved for $24 \mathrm{~h}$ and subsequently treated for $24 \mathrm{~h}$ with IL- $1 \beta$ or $b$ FGF at different concentrations. Data are expressed as fold of control of $\left({ }^{3} \mathrm{H}\right)$ thymidine incorporation $(m e a n \pm S D ; n=3)$, ${ }^{* *} P<0.01$, ${ }^{* * *} P<0.001$. B: Proliferation of $24 \mathrm{~h}$ starved NHLF induced by subsequent combined treatment with bFGF or/and lL- $1 \beta$ for $24 \mathrm{~h}$. A synergistic mitogenic effect at a concentration of bFGF at $10 \mathrm{ng} / \mathrm{ml}$ and $1 \mathrm{~L}-1 \beta$ at $10 \mathrm{pg} / \mathrm{ml}$ is observed, whereas a significant decrease of proliferation is measured when using a co-treatment with IL- $1 \beta$ at $100 \mathrm{pg} / \mathrm{ml}$. Data are expressed as fold of control of $\left({ }^{3} \mathrm{H}\right)$ thymidine incorporation $($ mean $\pm S D ; n=5-8)$, ${ }^{*} p<0.05$, $* * * p<0.001$.

Co-incubation of NHLF with IL- $1 \beta(10 \mathrm{pg} / \mathrm{ml})$ and bFGF $(10 \mathrm{ng} / \mathrm{ml})$ overadditively augmented proliferation of NHLF (Fig. IB): Under these conditions, $\left[^{3} \mathrm{H}\right]$ thymidine incorporation was approximately doubled compared to bFGF alone. In contrast, at the higher $1 \mathrm{~L}-1 \beta$ concentration of $100 \mathrm{pg} / \mathrm{ml}$ the cytokine reduced bFGF-induced $\left[{ }^{3} \mathrm{H}\right]$ thymidine incorporation by $\sim 41 \%$. This inhibitory effect of higher concentrations of IL-I $\beta$ on bFGF-induced lung fibroblast proliferation corroborates findings observed with $\mathrm{IL}-1 \beta$ treatment alone.

The second messenger CAMP has repeatedly been described to mediate antiproliferative effects in lung fibroblasts (Haag et al., 2008).

Whereas bFGF treatment $(24 \mathrm{~h}$ with $10 \mathrm{ng} / \mathrm{ml})$ alone did not influence intracellular cAMP concentrations in lung fibroblasts, $\mathrm{IL}-1 \beta$ treatment at concentrations of up to $10 \mathrm{pg} / \mathrm{ml}$ resulted in a modest yet concentration-dependent increase in CAMP (Fig. 2A). At IL-I $\beta$ concentrations higher than $10 \mathrm{pg} / \mathrm{ml} \mathrm{a}$ substantial increase in CAMP of up to 10 -fold (for $50 \mathrm{pg} / \mathrm{ml}$ IL-I $\beta$ ) compared to untreated controls was measured. In the additional presence of $b F G F(10 \mathrm{ng} / \mathrm{ml})$, while the concentration-dependent increase of CAMP by IL-I $\beta$ followed a comparable pattern, absolute cAMP levels in the lung fibroblasts were approximately doubled (Fig. 2B). The higher

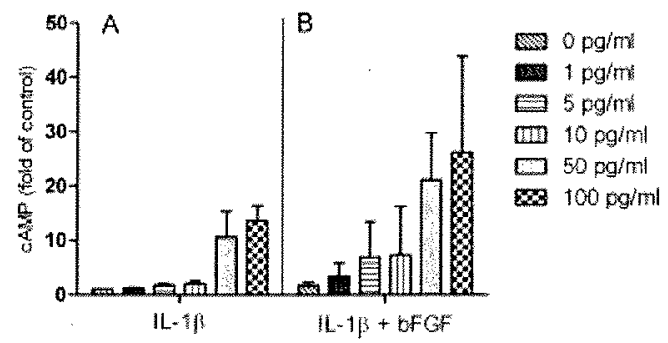

Fig. 2. Influence of treatment with IL-I $\beta$ and bFGF on cellular CAMP. NHLF were starved for $24 \mathrm{~h}$ and subsequently treated for $24 \mathrm{~h}$ with (A) IL-I $B$ alone or combined with $(B)$ bFGF $(10 \mathrm{ng} / \mathrm{ml})$. Data are expressed as fold of control (mean $\pm S D ; n=3$ ).
IL-I $\beta$ concentration shown to augment CAMP was also found to reduce bFGF-induced fibroblasts proliferation.

\section{bFGF increases the IL-I $\beta$-induced COX-2 expression in NHLF}

The mechanism behind the observed pattern of CAMPfollowing IL-I $\beta$ in presence or absence of bFGF was explored. As expected, incubation of NHLF for $24 \mathrm{~h}$ with IL- I $\beta$ concentration-dependently increased COX-2 expression (Fig. 3A-C). Thus, IL-I $\beta$ at the concentration of 10,50 , or $100 \mathrm{pg} / \mathrm{ml}$ induced COX -2 protein expression to $0.2 \pm 0.1 \%$, $11.5 \pm 5.2 \%$, and $14.1 \pm 4.4 \%$ of total arbitrary units (related to GAPDH, serving as the house-keeping protein) (Fig. 3A,B, $n=3$, mean $\pm S D$ ). COX-2 expression was already detectable I $\mathrm{h}$ after adding $\mathrm{IL}-\mathrm{I} \beta$ to the cells (data not shown). Surprisingly, co-treatment with $10 \mathrm{ng} / \mathrm{ml} \mathrm{bFGF}$, which by itself had no effect, significantly potentiated COX-2 expression by approximately threefold compared to IL-I $\beta$ alone.

Supportive evidence for this finding is obtained from COX-2 mRNA expression analyses (Fig. 3C). By analogy to COX-2 protein expression, bFGF potentiated accumulation of COX-2 transcripts following IL- $\mid \beta$ irrespective of the selected cytokine concentration. Addition of bFGF at $10 \mathrm{ng} / \mathrm{ml}$ to IL- I $\beta$ at 10,50 , and $100 \mathrm{pg} / \mathrm{ml}$ increased the expression of COX-2 mRNA by approximately 3.0-, 5.7-, and 2.4-fold compared to the corresponding $\mathrm{IL}-\mathrm{I} \beta$ concentration alone. bFGF alone did not increase accumulation of COX-2 transcripts. Therefore, we can conclude that the potentiating effect of bFGF on IL-I $\beta$ induced $C O X-2$ protein is predominantly due to enhanced transcription, although any post-translational regulation cannot be ruled out.

\section{bFGF potentiates IL- $\mid \beta$ induced formation of $P G E_{2}$ in NHLF}

In order to analyze whether the changes in COX-2 expression translate into corresponding changes of $\mathrm{PGE}_{2}$ release, this prostanoid was measured in conditioned medium following incubation of NHLF over $24 \mathrm{~h}$ with $\mathrm{LL}-\mathrm{I} \beta$ in the presence or absence of bFGF. IL- $1 \beta$ at concentrations of 10,50 , or $100 \mathrm{pg} / \mathrm{ml}$ increased accumulation of $P G E_{2}$ in the conditioned medium of NHLF to $0.2 \pm 0.1,5.7 \pm 0.8$, and $6.6 \pm 0.5 \mathrm{ng} / \mathrm{ml}$; 
A
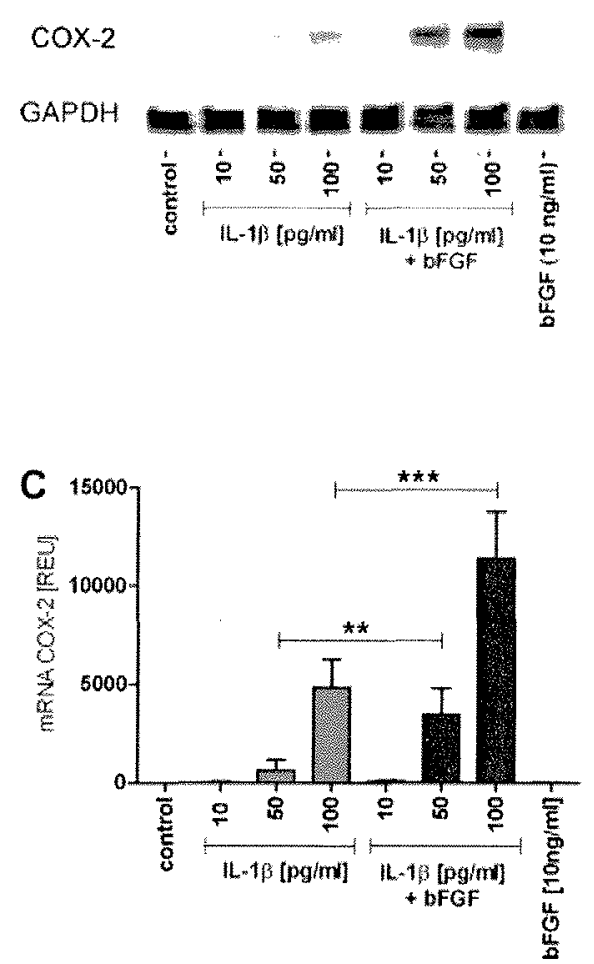
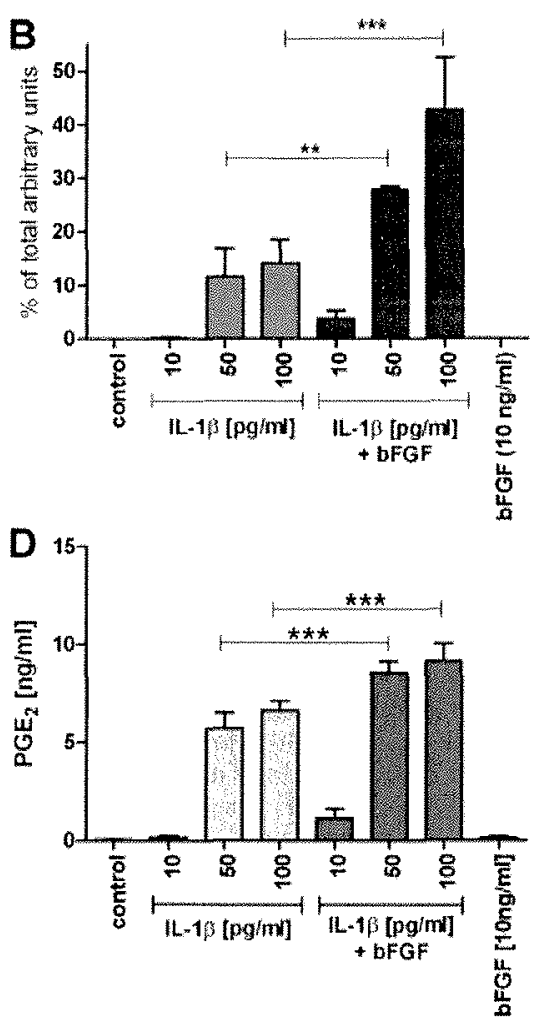

Fig. 3. Influence of treatment with IL- $\mid \beta$ and bFGF on COX-2 expression and subsequent PGE2 generation in NHLF. A: COX-2 protein expression of starved $(24 \mathrm{~h})$ NHLF after treatment $(24 \mathrm{~h})$ with bFGF $(10 \mathrm{ng} / \mathrm{ml})$ and/or IL- $1 \beta$ at different concentrations. The Western blot shown is a representative out of three independent experiments. B: Densitometric quantification of Western blots shows that bFGF significantly potentiated the IL-1 $\beta$-induced COX-2 expression. Data are expressed as percent of total arbitrary units $($ mean $\pm S D ; n=3)$, $* P<0.0 I$, ${ }_{* * *}^{*} P<0.001$. C: COX-2 gene expression of NHLF (same experimental setting as A). bFGF significantly potentiated IL-I $\beta$-induced COX-2 gene expression. Data are expressed as relative expression units (mean $\pm S D ; n=3$ ), $* * p<0.01$, $* * * P<0.001$. D: Prostaglandin E2 synthesis from $N H L F$ (same experimental setting as $A$ ). bFGF significantly potentiated IL-I $\beta$-induced $P_{G} E_{2}$ expression. Data show $P G E_{2}$ concentrations (mean $\pm S D$ $n=3)$, ${ }^{* * *} p<0.001$.

(Fig. 3D; $n=3$, means $\pm S D$ ). Control cells did not produce any detectable basal $P G E_{2}$. The distinct rise in accumulated $P G E_{2}$, when elevating $\mathrm{IL}-1 \beta$ from 10 to $50 \mathrm{pg} / \mathrm{ml}$, is in agreement with the COX-2 expression and CAMP levels. The additional presence of $b F G F$ further increased IL-I $\beta$-induced $P G E_{2}$ accumulation to $1.1 \pm 0.5 \mathrm{ng} / \mathrm{ml}$ of $P E_{2}$ at $10 \mathrm{pg} / \mathrm{ml}$; $8.6 \pm 0.6 \mathrm{ng} / \mathrm{ml}$ at $50 \mathrm{pg} / \mathrm{ml}$, and $9.2 \pm 0.9 \mathrm{ng} / \mathrm{ml}$ at $100 \mathrm{pg} / \mathrm{ml}$ IL.I $\beta$. These findings are in line with the results obtained for cAMP levels and COX-2 expression. bFGF treatment alone did not result in detectable $P G E_{2}$ accumulation.

The PDE4 inhibitor piclamilast elevates CAMP levels and inhibits the bFGF- and IL-I $\beta$-induced cell proliferation in NHLF

In order to identify the cyclic nucleotide hydrolyzing PDE isoenzymes in NHLF, we measured PDE activities by using isoenzyme-specific inhibitors and activators. As shown in Figure 4A CGMP hydrolysis substantially exceeds CAMP hydrolysis. The main CGMP-hydrolyzing PDE activities in these cells are PDE5 and PDEI, while CAMP hydrolysis is attributed to PDEI, PDE4, and to a minor extent to PDE3.

PDE4 subtype gene expression in NHLF were analyzed by RT-PCR. Under basal, unstimulated conditions PDE4A revealed as the major PDE4 subtype expressed followed by PDE4B. mRNA transcripts of the PDE4 subtypes $C$ and $D$ were very low and close to the limit of detection (Fig. 4B).
Since we assumed that the inhibition of bFGF-induced proliferation at high IL-I $\beta$ concentrations is attributed to increased CAMP levels and because PDE4 is expressed in NHLF we analyzed the effects of the selective PDE4 inhibitors piclamilast and roflumilast $\mathrm{N}$-oxide on proliferation under various conditions (Fig. 5).

Piclamilast reduced the bFGF and IL-I $\beta$-induced $\left[{ }^{3} \mathrm{H}\right]$ thymidine incorporation in a concentration-dependent manner (Fig. 5A). When IL-I $\beta$ was absent or present only at a low concentration $(10 \mathrm{pg} / \mathrm{ml})$, piclamilast afforded more than $20 \%$ inhibition of bFGFinduced $\left[{ }^{3} \mathrm{H}\right]$ thymidine incorporation in NHLF. When IL-I $\beta$ was present at a high concentration of $50 \mathrm{pg} / \mathrm{ml}$, which substantially increased COX-2, PGE 2 , and CAMP, piclamilast resulted in a maximum of $\sim 60 \%$ inhibition of bFGF-induced DNA synthesis. The inhibitory effect of the PDE4 inhibitor piclamilast on $\left[{ }^{3} \mathrm{H}\right]$ thymidine incorporation was reversible as proven by means of wash-out experiments (data not shown).

We obtained similar results using the PDE4 inhibitor roflumilast $\mathrm{N}$-oxide (Fig. 5B), which also inhibited $\left[{ }^{3} \mathrm{H}\right]$ thymidine incorporation in NHLF in a IL-I $\beta$-dependent manner to a maximum of $\sim 60 \%$. Interestingly, the inhibitory effect was fully abolished by simultaneous treatment with the COX-1/2 inhibitor indometacin (Fig. 5C). This supports our hypothesis that the $1 L$ - $\mid \beta$-induced $P G E_{2}$ formation and subsequent CAMP generation provides the basis for the antiproliferative efficacy of PDE4 inhibition. 

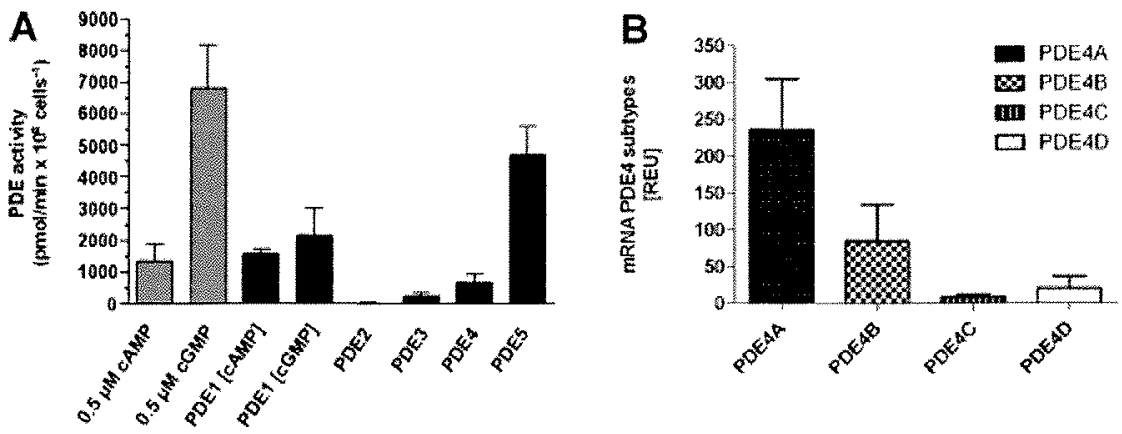

Fig. 4. Activity of PDE isoenzymes and PDE4 subtype gene expression in NHLF. A: PDE isoenzyme activities. NHLF were analyzed for total CAMP, CGMP, PDEI (CAMP and CGMP), PDE2, PDE3, PDE4, and PDE5 activities. Data are given as pmol/min $\times 10^{8} \mathrm{cells} \mathrm{s}^{-1}(\mathrm{mean} \pm \mathrm{SD} ; \mathrm{n}=3)$. B: PDE4 subtype gene expression of unstimulated NHLF. Data are expressed as relative $m R N A$ expression units $(R E U, m e a n \pm S D ; n=9)$.

In addition to PDE4 also a minor PDE3 activity was detected in NHLF, and therefore potential effects of a selective PDE3 inhibitor motapizone were explored. Both in the presence and absence of IL-I $\beta$ the PDE3 inhibitor alone did not affect bFGF-induced DNA synthesis in NHLF. On the other hand, in the presence of IL-I $\beta$ (but not in its absence) motapizone further accentuated the reduction of bFGF-induced $\left[{ }^{3} \mathrm{H}\right]$ thymidine incorporation by the PDE4 inhibitor piclamilast (Fig. 6).

\section{High levels of CAMP block NHLF in the GI phase of} their cell cycle

In order to extend our findings obtained by measurements of $\left[{ }^{3} \mathrm{H}\right]$ thymidine incorporation we next performed flow cytometric cell cycle analysis of NHFL under the various conditions described before. As illustrated in Figure 7, starving of NHLF for $24 \mathrm{~h}$ arrested most of the cells in GI phase $(91.2 \pm 1.8 \%, n=6$, means $\pm S D)$. As expected from the measurements of DNA synthesis, co-incubation of starved cells with $b F G F$ at $10 \mathrm{ng} / \mathrm{ml}$ and $I L-1 \beta$ at $10 \mathrm{pg} / \mathrm{ml}$ induced proliferation most efficiently resulting in an increase of the proportion of S-phase cells to $19.9 \pm 1.0 \%$, compared to bFGF alone with $12.5 \pm 0.8 \%$ and $2.2 \pm 0.5 \%$ for controls. Inhibition of PDE4 reduced the bFGF-induced increase of the proportion of NHLF in the S-phase by arresting cells in GI. This effect of the PDE4 inhibitor was observed following incubation with bFGF on its own and was found accentuated with increasing concentrations of IL-I $\beta$. Gene expression analyses showed significant down-regulation of the GI/S phase transition controlling Cyclins DI and EI as well as the cyclin-dependent kinases 6 and 2 under conditions of PDE4 inhibition (Fig. 8A-D), which is in line with investigations of other groups (L'Allemain et al., 1997; Musa et al., 1999; Lee and Kay, 2003). Taken together, results of the flow cytometric cell cycle analysis corroborate findings from measurements of $\left[{ }^{3} \mathrm{H}\right]$ thymidine incorporation.

\section{Discussion}

Human lung fibroblasts are major structural cells orchestrating repair and remodeling in ailments such as IPF, asthma, or COPD. Persistent activation of these cells may foster their

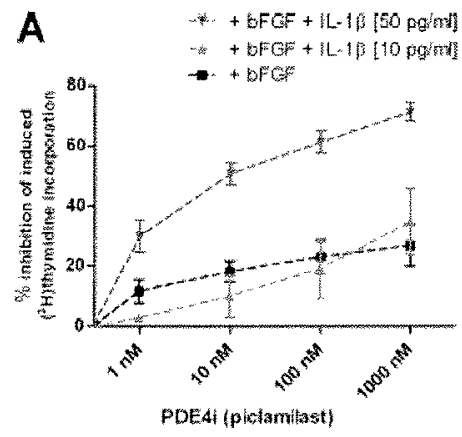

B

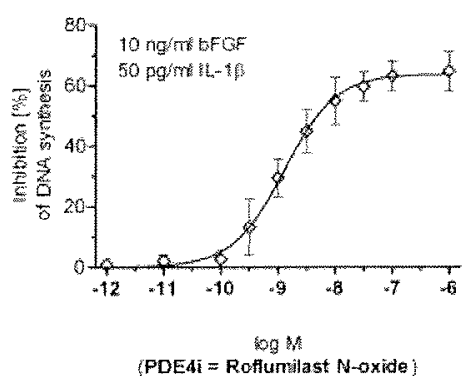

C

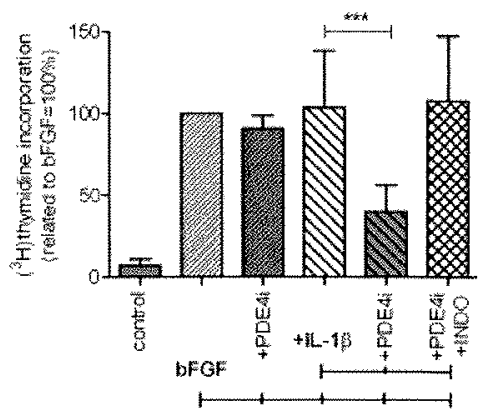

Fig. 5. PDE4 inhibitors inhibit the IL-I $\beta$ - and bFGF-induced proliferation in a IL-I $\beta / C O X$-2-dependent manner. A: Concentration-response relationship of the PDE4 inhibitor piclamilast. NHLF were starved for $24 \mathrm{~h}$, subsequently treated with piclamilast at $I \mu M$ and stimulated over $24 \mathrm{~h}$ with bFGF alone or in combination with IL. $1 \beta$. Data are expressed as percent inhibition of induced $\left({ }^{3} \mathrm{H}\right)$ thymidine incorporation (mean \pm SD; $n=3$ ). B: Concentration-response relationship of the PDE4 inhibitor roflumilast $N$-oxide. NHLF were starved for 48 h, subsequently treated with the PDE4i $(I \mu \mathrm{M})$, and then stimulated over $24 \mathrm{~h}$ with bFGF and $\mathrm{IL}-1 \beta$. Data are expressed as percent inhibition of induced $\left({ }^{3} \mathrm{H}\right)$ thymidine incorporation (mean $\pm S D ; n=7),{ }^{*}<0.05$. C: NHLF were starved for 48 hand subsequently stimulated with $b F G F(10 \mathrm{ng} / \mathrm{ml})$. Starved $\mathrm{NHLF}$ were pretreated with either the PDE4 inhibitor roflumilast $N$-oxide (I $\mu \mathrm{M}$ ) and/orindomethacin (INDO, $10 \mu \mathrm{M})$ and subsequently stimulated with bFGF $(10 \mathrm{ng} / \mathrm{ml})$ and IL- $1 \beta(50 \mathrm{pg} / \mathrm{ml})$. The COX inhibitor INDO reversed the proliferation reducing effect of the PDE4 inhibitor under conditions of IL- $I \beta$ co-treatment. Data are expressed as percent related to bFGF treated cells (mean $\pm S D ; n=9$ ), ${ }^{* * *} p<0.001$. 


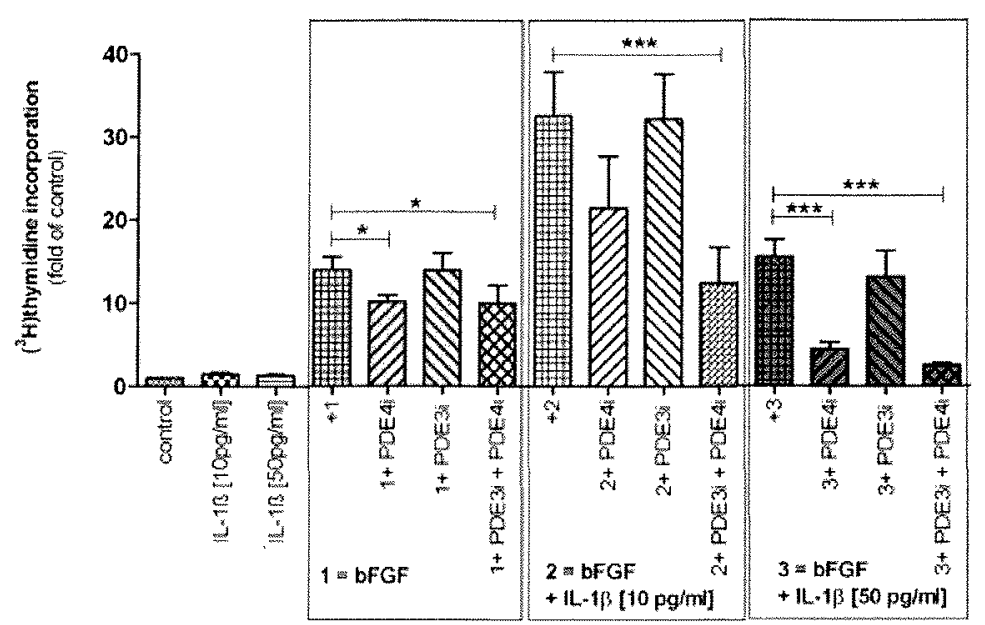

Fig. 6. A PDE4 but not PDE3 inhibitor reduces proliferation of NHLF induced by bFGF plus/minus IL-I $\beta$. NHLF were starved for $24 \mathrm{~h}$ and subsequently stimulated with bFGF $(10 \mathrm{ng} / \mathrm{ml})$ alone (1) or together with IL-I $\beta$ at $10 \mathrm{pg} / \mathrm{ml}$ (2) or $50 \mathrm{pg} / \mathrm{ml}$ (3). Under these conditions the PDE4i piclamilast $(1 \mu \mathrm{M})$ reduced proliferation significantly. Treatment with the PDE3 inhibitor motapizone (I $\mu M$ ) alone showed no reducing effect but may have some additional effects on top of the PDE4 inhibitor. Data are expressed as fold of control of $\left({ }^{3} \mathrm{H}\right)$ thymidine incorporation (mean \pm SD; $n=3),{ }^{*} p<0.05,{ }^{* * * *} p<0.001$

inappropriate proliferation, migration, production of extracellular matrix proteins, contractile properties, amongst others, and together will support fibrotic remodeling (Bjornsdottir and Cypcar, 1999; Chung, 2001; Gross and Hunninghake, 200 I; Dempsey et al., 2006).

Previous data indicate the spatial heterogeneity of fibroblasts within the healthy lung and the phenotypic differences of lung fibroblasts between normal and disease state (Kotaru et al., 2006). For example, Kotaru and coworkers demonstrated that there are differences in morphology, proliferation, $\alpha-S M A$, and procollagen expression in primary lung fibroblast obtained from proximal airways compared to those derived from distal lung parenchyma of asthmatic patients.

The question still persists, whether these different phenotypes are derived from distinct subpopulations with unique progenitors or represent different stages of differentiation from a common progenitor (Phan, 2008).
We used NHLF for our studies. These primary cells from healthy donors derive from several different parts of the lung and therefore reflect the naturally occurring heterogeneity of fibroblasts in this tissue.

Proliferation is controlled by divergent (Huang et al., 2008) and sometimes opposing signals (Dumaz and Marais, 2005). To understand the mechanistic basis of fibrotic hyperproliferation in respiratory diseases, the complex network of numerous cytokines, growth factors, and other mediators must be considered. Since IL-I $\beta$ and bFGF are found to be increased in lungs of patients with asthma, COPD, and IPF (Gross and Hunninghake, 200I; Jeffery, 200I; Barnes, 2003), their interaction may be of interest in the pathogenesis of respiratory diseases with fibrotic components.

Previous studies investigated the effects of IL-I $\beta$-induced $P G E_{2}$ and $b F G F$ on proliferation on various cell types. Overall these studies show that their effects on proliferation is

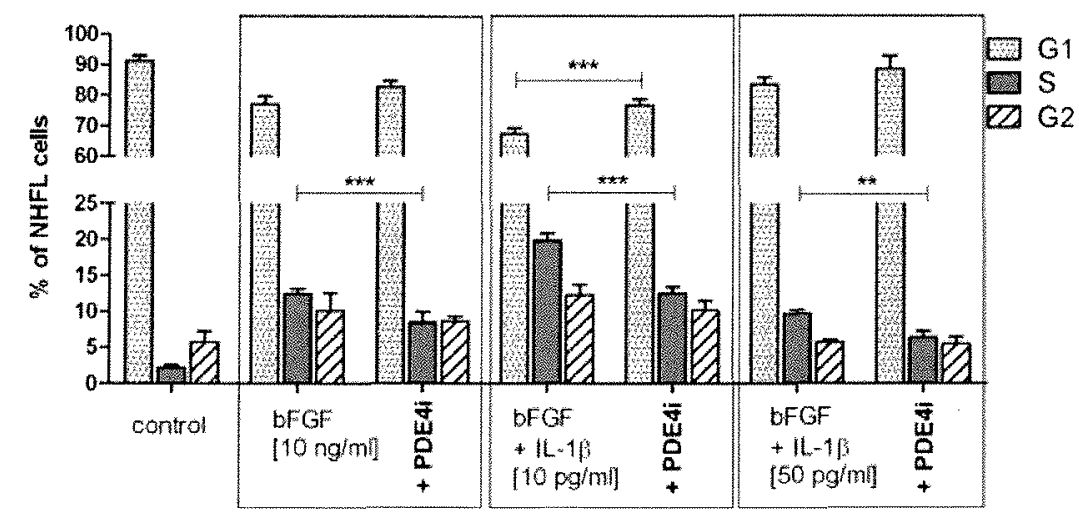

Fig. 7. PDE4 inhibition provokes G I-block in NHLF. Flow cytometric cell cycle analyses from $24 \mathrm{~h}$ starved NHLF (control) after induction of proliferation with either bFGF $(10 \mathrm{ng} / \mathrm{ml})$ alone or in combination with $1 \mathrm{~L}-1 \beta$ at 10 or $50 \mathrm{pg} / \mathrm{ml}$ are shown. PDE4 inhibition (piclamilast, I $\mu \mathrm{M})$ provokes a GI-block, which is most pronounced at a concentration of IL-I $\beta$ at $50 \mathrm{pg} / \mathrm{ml}$. Data are expressed as percent of total cells number

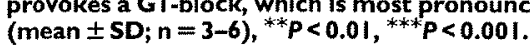



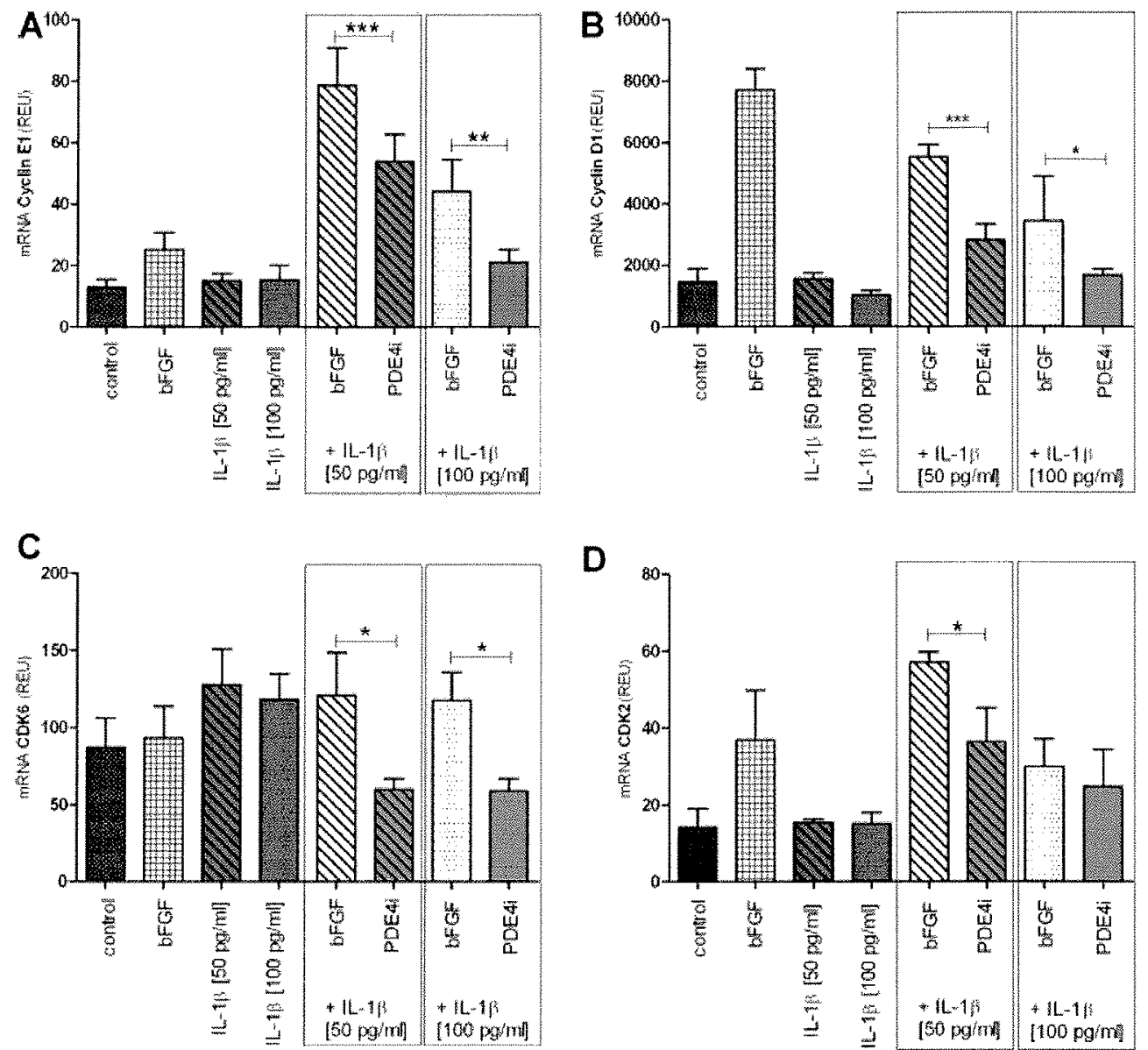

Fig. 8. Gene expression of GI/S-transition regulating cyclins and cyclin-dependent kinases is downregulated by means of PDE4 inhibition in NHLF. RT-PCR gene expression analyses from $24 \mathrm{~h}$ starved NHLF (control) after induction of proliferation with either bFGF (10 ng/ml) alone or in combination with $1 L-1 \beta$ at 50 or $100 \mathrm{pg} / \mathrm{ml}$. Additionally, treatment with the PDE4 inhibitor piclamilast $(1 \mu M)$ reduced gene expression of cyclin $E \mathrm{I}$ (A), cyclin DI (B), CDK6 (C), and CDK2 (D) significant. Data are expressed as relative expression units $($ mean $\pm S D ; n=3-4),{ }^{*}=0.05,{ }^{* *} P<0.01$, p<0.001.

contingent on the concentrations of these factors or the investigated cell types (Cozzolino et al., 1990; Bourcier et al., 1995; White et al., 2008).

In our own studies we analyzed the interaction of IL-I $\beta$ and bFGF on lung fibroblast proliferation and related mechanisms such as COX-2 induction, $\mathrm{PGE}_{2}$ release, and $\mathrm{CAMP}$ synthesis. That cAMP reduces proliferation of human lung fibroblasts has been repeatedly described in the past and more recently the CAMP-GEF (GTP exchange factor) Epac, yet not protein kinase $A$, was disclosed to mediate this antimitogenic effect (Schmitt and Stork, 200I; Sanchez and Moreno, 2002; Liu et al., 2004).

Our own data show that IL- $\mid \beta$ treatment alone is able to increase proliferation significantly at a concentration of $10 \mathrm{pg} /$ $\mathrm{ml}(2.2$-fold, $P$-value: $<0.01)$ to an extent, which however, is by far less than that reached by incubation with bFGF. This is in agreement with the results of White et al. (2008).

White et al. concluded that IL-I $\beta$ induces proliferation by triggering low concentrations of $P G E_{2}$, thereby activating $G_{i}$ coupled $\mathrm{EP}_{3}$-receptor, reducing $\mathrm{CAMP}$ and promoting proliferation. In contrast, our own data show that low IL-IB concentrations trigger only a very small amount of $P G_{2}$, which does not reduce intracellular CAMP. Instead, these low concentrations of $P G E_{2}$ already seem to increase CAMP. In line, under our experimental conditions $\mathrm{PGE}_{2}$ in a concentration range from I PM to $I \mu M$ concentration-dependently diminished bFGF-induced $\left[{ }^{3} \mathrm{H}\right]$ thymidine incorporation to a maximum efficacy of $\sim 70 \%$ and with a half-maximum inhibition at $2.1 \mathrm{nM}$ (data not shown). In contrast, White and colleagues described a biphasic effect of $P G E_{2}$ on the proliferation of human lung fibroblasts under their experimental conditions with a maximum mitogenic effect attained at about $3 \mathrm{nM}$. Differences in cell types, their expression pattern of $\mathrm{PGE}_{2}$ receptors $\left(E P_{1}-E P_{4}\right)$ and their coupling to intracellular signaling cascades as well as cell culture conditions may explain these inconsistent findings. Therefore, we assume that in our experimental system the mitogenic effects of $I L-I \beta$ are unrelated to $P G E_{2}$ and $C A M P$. An explanation for the mitogenic effect of IL-1 $\beta$ may be an influence on MAPK pathway as published by several other groups (Scherle et al., 1997; Kida et al., 2005).

The current report demonstrates that in normal human lung fibroblasts the mitogenic potential of bFGF is accentuated by low concentrations of $I L-I \beta(\leq 10 \mathrm{pg} / \mathrm{ml})$. Such a synergism has previously been described in different cell types, for example, in rat aortic smooth muscle cells (Bourcier et al., 1995), in human endothelial cells (Norioka et al., 1994) or in primary rabbit and 
human dermal fibroblasts (Bond et al., 1998). One may hypothesize that converging downstream signaling shared by bFGF and IL- $\beta$ accounts for this observation, yet the precise molecular mechanisms are not well understood.

The observation that IL-I $\beta$ potentiates bFGF-induced DNA synthesis in NHLF was limited to low concentrations of the cytokine $(10 \mathrm{pg} / \mathrm{ml})$ while higher concentrations of $1 \mathrm{~L}-1 \beta$ progressively reduced proliferation. At these higher concentrations of IL-1 $\beta$ intracellular CAMP strongly increased that may explain the antiproliferative effect of $I L-1 \beta$. Since the higher $I L-I \beta$ concentrations up-regulated $C O X-2$ resulting in an increased accumulation of $\mathrm{PGE}_{2}$ one may assume that the prostanoid senses $\mathrm{EP}_{2}$ and $\mathrm{EP}_{4}$ receptor coupled to heterotrimeric $G_{s}$ protein, and that finally adenylyl cyclase activity accounts for the rise in CAMP. Indeed, human lung fibroblasts express $E P_{2}$ and $E P_{4}$ receptors with $E P_{2}$ being the predominant subtype (Huang et al., 2007; Haag et al., 2008).

A major finding of the current study was that in NHLF bFGF strongly potentiated the induction by $I L-I \beta$ of $C O X-2$, and consequently, the increase in $\mathrm{PGE}_{2}$ and $C A M P$ secondary to the cytokine. This crosstalk between FGF and IL-I $\beta$ has been described earlier in human osteosarcoma cells, yet its mechanistic origin remains to be explored (Laulederkind et al., 2000).

In aggregate, there is a high level of complexity in the interactions between IL-I $\beta$ and bFGF to control proliferation of lung fibroblasts. Whereas bFGF-induced proliferation is potentiated by lower concentrations of IL-I $\beta$, by a separate mechanism bFGF amplifies the potential of higher concentrations of the cytokine to diminish proliferation, thus limiting its own mitogenic effects. As mentioned before bFGF and $I L-I \beta$ have been described to be up-regulated in various respiratory diseases where excessive proliferation of lung fibroblasts occurs. Strategies to increase or stabilize intracellular CAMP levels may represent a therapeutic perspective in fibrotic conditions, a view shared by others (Liu et al., 2004; Dunkern et al., 2007; Haag et al., 2008).

Cyclic AMP is degraded by several PDE isoenzymes, as a corollary inhibition of PDEs augments CAMP. PDE isoenzymes activities were analyzed in primary human lung fibroblasts and the presence of PDEI, PDE3, and PDE4 hydrolyzing CAMP as well as PDEI and PDE5 hydrolyzing CGMP was revealed.

Based on this analysis we investigated the effects of a PDE4 and a PDE3 inhibitor on proliferation of human lung fibroblasts. The possible role of PDEI cannot be further assessed due to the lack of specific inhibitors for this isoenzyme. Complete and selective inhibition of PDE4 by piclamilast at I $\mu \mathrm{M}$ reduced proliferation of these cells, as it has been described on various other cell types (Hatzelmann and Schudt, 200I), however to a modest extent. The inhibitory efficacy of this compound on proliferation strongly increased by simultaneous treatment with IL-I $\beta$, which somehow could be expected due to the enhancement of CAMP. Therefore, PDE4 inhibition strengthens the $I L-1 \beta$-induced $P G E_{2}$-driven biological response, namely the decrease in proliferation. This is further supported by our data showing that treatment with a cyclooxygenase

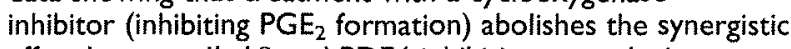
effect between IL-I $\beta$ and PDE4-inhibition on reducing proliferation.

Whether the effect of piclamilast is due to inhibition of the four subtypes PDE4A, B, C, or D is rather unclear. To address this aspect we performed quantitative real-time PCR experiments. We generated primer and probes, displaying similar efficacy on recombinant PDE4 subtype plasmid DNA, and used them for relative quantification of PDE4 subtype expression in human lung fibroblasts. Our results demonstrate an inhomogeneous mRNA expression pattern. PDE4A turned out to be the predominant subtype, followed by subtype B. In contrast, the expression of PDE4 subtypes $C$ and D was low. Since we detect all four PDE4 subtypes the antiproliferative effect of piclamilast, which is known to be a pan-PDE4 subtype-specific inhibitor, in principal can be due to inhibition of each of these subtypes, although PDE4A and/or $4 B$ have the highest probability in this respect.

Since besides PDE4 also CAMP-hydrolyzing PDE3 was detected in human lung fibroblasts, we also analyzed the effect of PDE3 inhibition on proliferation. PDE3 inhibition via motapizone by itself did not affect proliferation, however, it potentiates the antiproliferative effect of PDE4 inhibition. This finding confirms the hypothesis of the role of different PDEs in generating subcellular signaling compartments and nucleotide pools (Conti and Beavo, 2007). We hypothesize that under conditions of PDE4 inhibition the CAMP pool generated by adenyl cyclase activity increases and looses confinement, consequently diffusing into compartments of the cell, where PDE3 gets access to CAMP and will hydrolyze it. In this case a PDE3 inhibitor becomes effective in blocking proliferation of these cells, since it even more increases the CAMP pool originally controlled by PDE4 only (Zaccolo et al., 2006).

In order to elucidate the mechanism of proliferation inhibition in more detail we performed cell cycle analysis and asked, whether the inhibition of proliferation by PDE4 inhibitors under concomitant incubation with $\mathrm{IL}-\mathrm{I} \beta$ induces changes in cell cycle distribution. Overall, the cell cycle analysis reflected findings in the proliferation assays. In comparison to starved cells bFGF increased the proportion of S-phase cells, which was potentiated by lower concentrations of IL-I $\beta$. At higher concentrations of IL-I $\beta$ the percentage of S-phase cells decreased again. A PDE4 inhibitor on its own reduced the number of S-phase cells following bFGF by inducing a partial GI-arrest. By analogy to results from measurements of $\left[{ }^{3} \mathrm{H}\right]$ thymidine incorporation co-incubation with IL- I $\beta$ potentiated the efficacy of a PDE4 inhibitor in inducing partial GI arrest. The GI arrest was accompanied by a decrease in Cyclin EI, DI, and cyclin-dependent kinase 4 and 6 mRNA expression, which gives some mechanistical insight about the influence of PDE4 inhibitors/cAMP on cell cycle control. These results are in line with investigations by other groups using various cell types (L'Allemain et al., 1997; Musa et al., 1999; Stuart et al., 2000; Lee and Kay, 2003).

In summary, we have described the interaction of bFGF and IL-I $\beta$ on proliferation of human lung fibroblasts. Both cytokines are assumed to be involved in pathophysiological processes leading to fibrosis in various respiratory disorders. In particular, the presence of $I L-I \beta$ may be considered in view of ongoing inflammatory processes such as those described in IPF. In our experimental system it was shown that IL-I $\beta$ may either drive the fibrotic process by its ability to stimulate proliferation on its own but also by potentiating the action of bFGF, or that IL-I $\beta$ may be antiproliferative by inducing COX-2 and subsequently enhances $P G E_{2}$. It is possible that the balance between these two cytokines will determine, at least in part, whether fibrotic processes are ongoing or tissue homeostasis is maintained.

Up to now there is no therapy available addressing the fibrotic component of, for example, IPF, COPD, or asthma. PDE4 inhibitors as, for example, roflumilast, which succeeded recently in phase III trials in COPD, are well known antiinflammatory agents (Hatzelmann and Schudt, 200I) by their ability to increase intracellular CAMP. Our in vitro investigations suggest that these drugs might offer additional therapeutic benefit by inhibiting proliferation of lung fibroblasts especially under pathologic conditions of enhanced $I L-I \beta$ and $\mathrm{PGE}_{2}$. This might be of particular importance since different groups (Wilborn et al., 1995; Vancheri et al., 2000) have shown, that the capability of lung fibroblasts to produce antiproliferative $P G E_{2}$ levels is diminished in patients with pulmonary fibrosis. 
It might therefore be important to boost the signal transduction initiated by $P G E_{2}$ via inhibition of $C A M P$ hydrolysis by PDE4 inhibitors.

Roflumilast $\mathrm{N}$-oxide has already been shown to be effective in bleomycin-induced lung fibrosis in mice, in particular when administered in a therapeutic protocol (Cortijo et al., 2009). This is of paramount interest since corticosteroids, standard antiinflammatory drugs failed in this therapeutic protocol and did not show efficacy in clinical trials with IPF patients. Whether PDE4 inhibitors may reveal a favorable profile on fibrotic conditions in man remains to be ascertained.

\section{Literature Cited}

Agostini C. Gurrieri C. 2006. Chemokine/cytokine cocktail in idiopathic pulmonary fibrosis Proc Am Thorac Soc 3:357-363.

American Thoracic Society, 2000. Idiopathic pulmonary fibrosis: Diagnosis and treatment. International consensus statement. American Thoracic Society (ATS), and the European International consensus statement. American Thoracic Society (ATS),
Respiratory Society (ERS). Am I Respir Crit Care Med I6I:646-664.

Respiratory Society (ERS). Am J Respir Crit Care Med I61:646-664.
Andersson-Sjoland A, de Alba CG, Nihlberg K, Becerril C, Ramirez R, Pardo A,

Andersson-Sjoland A, de Alba CG, Nihlberg K, Becerril C, Ramirez R, Pardo A,
Westergren-Thorsson $G$, Selman M. 2008. Fibrocytes are a potential source of lung

Westergren-Thorsson $G$, Selman $M$. 2008. Fibrocytes are a potential source of lung
fibroblasts in idiopathic pulmonary fibrosis. Int / Biochem Cell Biol 40:2129-2140.

Barnes PJ. 2003. New concepts in chronic obstructive pulmonary disease. Annu Rev Med $54: 113-129$.

Bauer AC, Schwabe U. 1980. An improved assay of cyclic 3',5'-nucleotide

phosphodiesterases with QAE-Sephadex columns. Naunyn Schmiedebergs Arch

Bjornsdottir US, Cypcar DM. 1999. Asthma: An inflammatory mediator soup. Allergy 54:5561

Bond $M$, Fabunmi RP, Baker AH, Newby AC. 1998. Synergistic upregulation of metalloproteinase- 9 by growth factors and inflammatory cytokines: An absolute requirement for transcription factor NF-kappa B. FEBS Lett 435:29-34.

Borbe HO, Hilboll G. Prop G. 1986. Inhibition of human platelet aggregation by motapizone via an increase in intracelfutar cAMP. Agents Actions Suppl 20:249-257.

ourcier T, Dockter M, Hassid A. 1995. Synergistic interaction of interleukin-I beta and growth factors in primary cultures of rat aortic smooth muscle cells. J Cell Physiol 164:644

Chung KF. 2001. Cytokines in chronic obstructive pulmonary disease. Eur Respir I Suppl $34: 50 s-59 s$.

Conti M, Beavo J. 2007. Biochemistry and physiology of cyclic nucleotide phosphodiesterases: Essential components in cyclic nucleotide signaling. Annu Rev Biochem 76:481-511.

Cortijo], Iranzo A, Milara X, Mata M, Cerda-Nicolas M, Ruiz-Sauri A, Tenor H, Hatzelmann A, Morcillo EJ. 2009. Roflumilast, a phosphodiesterase 4 inhibitor, alleviates bleomycininduced lung injury. Br ] Pharmacol 156:534-544.

Cozzolino F, Torcia M, Aldinucci D, Ziche M, Almerigogna F, Bani D, Stern DM. 1990. Interleukin $I$ is an autocrine regulator of human endothelial cell growth. Proc Natl Acad SC USA 87:6487-649

Dempsey Of, Kerr KM, Gomersall L, Remmen H, Currie GP. 2006. Idiopathic pulmonary fibrosis: An update. QJM 99:643-654.

Dumaz N, Marais R. 2005. Integrating signals between CAMP and the RAS/RAF/MEK/ERK signalling pathways. Based on the anniversary prize of the Gesellschaft fur Biochemie und Molekularbiologie Lecture delivered on 5 July 2003 at the Special FEBS Meeting in Brussels. FEBS ) 272:349 -3504

Dunkern TR, Feurstein D, Rossi GA, Sabatini F, Hatzelmann A. 2007. Inhibition of TGF-beta induced lung fibroblast to myofibroblast conversion by phosphodiesterase inhibiting drugs and activators of soluble guanylyl cyclase. Eur I Pharmacol 572:12-22

GiriSN, Hyde DM, Hollinger MA. 1993. Effect of antibody to transforming growth factor beta on bleomycin induced accumulation of lung collagen in mice. Thorax 48:959-966.

Goldring MB, Birkhead ], Sandell LJ, Kimura T, Krane SM. 1988. Interleukin I suppresses expression of cartilage-specific types II and IX collagens and increases types I and III collagens in human chondrocytes. J Clin Invest 82:2026-2037.

Gross T], Hunninghake GW. 200I. Idiopathic pulmonary fibrosis. N Engl] Med 345:517-525.

Haag S, Warnken M, Juergens UR, Racke K. 2008. Role of Epacl in mediating anti-proliferative effects of prostanoid EP(2) receptors and CAMP in human lung fibroblasts. Naunyn Schmiedebergs Arch Pharmacol 378:617-630

Hatzelmann A, Schudt C. 2001. Anti-inflammatory and immunomodulatory potential of the novel PDE4 inhibitor roflumilast in vitro. ) Pharmacol Exp Ther 297:267-279.

Herrmann M, Selige f, Raffael S, Sachs G, Brambilla A, Klein T, 2007. Systematic expression profiling of the gastric $\mathrm{H}+/ \mathrm{K}+$ ATPase in human tissue. Scand I Gastroenterol 42:1275 1288.

Huang S, Wettlaufer SH, Hogaboam C, Aronoff DM, Peters-Golden M. 2007. Prostaglandin $E(2)$ inhibits collagen expression and proliferation in patient-derived normal lung E(2) inhibits collagen expression and prolferation in patient-derived normal lung Physiol 292:L405-L413.

Huang SK, Wettlaufer SH, Chung J, Peters-Golden M. 2008. Prostaglandin E2 inhibits specific lung fibroblast functions via selective actions of PKA and Epac-1. Am J Respir Cell Mol Biol lung fibroblast
$39: 482-489$

Inoue $Y$, King TE, Jr., Barker E, Daniloff E, Newman LS. 2002. Basic fibroblast growth factor and its receptors in idiopathic pulmonary fibrosis and lymphangioleiomyomatosis. Am J Respir Crit Care Med 166:765-773.

Jeffery PK. 200I. Remodeling in asthma and chronic obstructive lung disease. Am J Respir Crit Care Med 164:S28-\$38.

Khalil N, Xu YD, O'Connor R, Duronio V. 2005. Proliferation of pulmonary interstitial fibroblasts is mediated by transforming growth factor-betal -induced release of extracellular fibroblast growth factor -2 and phosphorylation of $\mathrm{p} 38$ MAPK and NNK. J Biol Chem 280:43000-43009.

Kida Y, Kobayashi M, Suzuki T, Takeshita A, Okamatsu Y, Hanazawa S, Yasui T, Hasegawa K. 2005 , Interleukin-I stimulates cytokines, prostaglandin E2 and matrix metalloproteinase2005. Interleukin-l stimulates Cytokines, prostaglandin E2 and matrix metalloproteinase-
production via activation of MAPK/AP-I and NF-kappaB in human gingival fbroblasts. Cytokine 29:159-168.
Kohyama T, Liu X, Zhu YK, Wen FQ, Wang HJ, Fang Q, Kobayashi T, Rennard SI. 2002. Phosphodiesterase $\mathbf{4}$ inhibitor cilomilast inhibits fibroblast-mediated collagen gel degradation induced by tumor necrosis factor-alpha and neutrophil elastase. Am J Respir Cell Mol Biol 27:487-494

Kohyama T, Liu X, Wen FQ, Kobayashi T, Fang Q, Abe S, Cieslinski L, Barnette MS, Rennard Sl. 2004. Cytokines modulate cilomilast response in lung fibroblasts. Clin Immuno $111: 297-302$

Kolb M, Margetts PJ, Anthony DC, Pitossi F, Gauldie J. 200I. Transient expression of IL-I beta induces acute lung

Kotaru C. Schoonover KJ, Trudeau JB, Huynh ML, Zhou X, Hu H, Wenzel SE. 2006. Regional fibroblast heterogeneity in the lung: Implications for remodeling. Am J Respir Crit Care Med 173:1208-1215.

Kranenburg AR, Willems-Widyastuti A, Mooi WJ, Saxena PR, Sterk PJ, de Boer WI, Sharma HS. 2005. Chronic obstructive pulmonary disease is associated with enhanced bronchial expression of FGF-I, FGF-2, and FGFR-1. / Pathol 206:28-38.

L'Allemain G, Lavole JN, Rivard N, Baldin V, Pouyssegur J. 1997. Cyclin DI expression is a major target of the CAMP-induced inhibition of cell cycle entry in fibroblasts. Oncogene 14:1981-1990.

Lappalainen U, Whitsett JA, Wert SE, Tichelaar JW, Bry K. 2005. Interleukin-I beta causes pulmonary inflammation, emphysema, and airway remodeling in the adult murine lung. Am Mol Biol 32:311-318.

Laulederkind S], Kirtikara K, Raghow R, Ballou LR. 2000. The regulation of PGE(2)

biosynthesis in MG-63 osteosarcoma cells by $1 L-I$ and FGF is cell density-dependent. ExP Cell Res 258:409-416.

Lee HT, Kay EP. 2003. Regulatory role of CAMP on expression of Cdk4 and P27(Kipl) by inhibiting phosphatidylinositol 3-kinase in corneal endothelial cells. Invest Ophthalmol Vis Sci 44:3816-3825.

Liu X, Ostrom RS, Insel PA. 2004. cAMP-elevating agents and adenylyI cyclase overexpression promote an antifibrotic phenotype in pulmonary fibroblasts. Am / Physiol Cell Physiol 286:C1089-Cl099.

Musa NL, Ramakrishnan M, Li J, Kartha S, Liu P, Pestell RG, Hershenson MB. 1999. Forskolin inhibits cyclin DI expression in cultured airway smooth-muscle cells. Am J Respir Cell Mo Biot 20:352-358.

Norioka K, Mitaka T, Mochizuki Y, Hara M, Kawagoe M, Nakamura H. 1994, Interaction of interleukin-l and interferon-gamma on fibroblast growth factor-induced angiogenesis. Jpn Cancer Res 85:522-529.

Palmer JN, Hartogensis WE, Patten M, Fortuin FD, Long CS. 1995. Interleukin-I beta induces cardiac myocyte growth but inhibits cardiac fibroblast proliferation in culture.J Clin Invest

Phan SH. 2008. Biology of fibroblasts and myofibroblasts. Proc Am Thorac Soc 5:334-337 Piguet PF, Vesin C, Grau GE, Thompson RC. 1993. Interleukin I receptor antagonist (IL-I ra) prevents or cures pulmonary fibrosis elicited in mice by bleomycin or silica. Cytokine 5:57Rabe KF, Tenor H, Dent G, Schudt C, Liebig S, Magnussen H. 1993. Phosphodiesterase isozymes modulating inherent tone in human airways: Identification and characterization. Am J Physiol 264:L458-L464.

Raeburn D, Underwood SL, Lewis SA, Woodman VR, Battram CH, Tomkinson A, Sharma S, Jordan R, Souness JE, Webber SE. 1994. Anti-inflammatory and bronchodilator propertie of RP 7340I, a novel and selective phosphodiesterase type IV inhibitor. BrJ Pharmacol $|13:| 423-|43|$.

Raines EW, Dower SK, Ross R. 1989. Interleukin-1 mitogenic activity for fibroblasts and smooth muscle cells is due to PDGF-AA. Science 243:393-396.

Sanchez T, Moreno If. 2002. Role of EP(1) and EP(4) PGE(2) subtype receptors in seruminduced 3 T 6 fibroblast cycle progression and proliferation. Am / Physiol Cell Physio 282:C280-C288.

cherle PA, Pratta MA, Feeser WS, Tancula EJ, Arner EC. 1997. The effects of IL-I on mitogen-activated protein kinases in rabbit articular chondrocytes. Biochem Biophys Res Commun 230:573-577.

Schmitt JM, Stork PJ. 200I. Cyclic AMP-mediated inhibition of cell growth requires the small G protein Rapl. Mol Cell Biol 21:367! -3683.

Spurzem IR, Rennard S1. 2005. Pathogenesis of COPD. Semin Respir Crit Care Med 26:142153.

Strieter RM. 2005. Pathogenesis and natural history of usual interstitial pneumonia: The whole story or the last chapter of a long novel. Chest 128:5265-532S.

Stuart WD, Maeda S, Khera P, Fagin JA, Clemens TL. 2000. Parathyroid hormone-related protein induces $G$ phase growth arrest of vascular smooth muscle cells. Am 」 Physiol Endocrinol Metab 279:E60-E67.

Thompson W]. Terasaki WL, Epstein PM, Strada SJ. 1979. Assay of cyclic nucleotide phosphodiesterase and resolution of multiple molecular forms of the enzyme. Adv Cyclic Nucleotide Res 10:69-92.

Togo S, Holz O, Liu X, Sugiura H, Kamio K, Wang X, Kawasaki S, Ahn Y, Fredriksson K, Skold CM, Mueller KC, Branscheid D, Welker L, Watz H, Magnussen H, Rennard SI. 2008. Lung fibroblast repair functions in patients with chronic obstructive pulmonary disease are altered by multiple mechanisms. Am I Respir Crit Care Med 178:248-260.

Togo S, Liu X, Wang X, Sugiura H, Kamio K, Kawasaki S, Kobayashi T, Ertt RF, Ahn Y, Holz O Magnussen H, Fredriksson K, Skold CM, Rennard S1. 2009. PDE4 inhibitors roflumilast and rolipram augment PGE2 inhibition of TGF-\{beta\}I-stimulated fibroblasts. Am J Physiol Lolipram Cell Mol Physiol 296:1959-1.969.

Vancheri C, Sortino MA, Tomaselli V, Mastruzzo C, Condorelli F, Bellistri G, Pistorio MP, Canonico PL, Crimi N. 2000. Different expression of TNF-alpha receptors and prostaglandin E(2)Production in normal and fibrotic lung fibroblasts: Potential implications prostaglandin $E(2)$ Production in normal and fibrotic lung fibroblasts: Potential implications
for the evolution of the inflammatory process. Am J Respir Cell Mol Biol 22:628-634.

White KE, Ding Q. Moore BB, Peters-Golden M. Ware LB, Matthay MA, OIman MA. 2008. Prostaglandin $E 2$ mediates IL-I beta-related fibroblast mitogenic effects in acute lung injury

through differential utilization of prostanoid receptors. J Immunol 180:637-646.
Wilborn J, Crofford LJ, Burdick MD, Kunkel SL, Strieter RM, Peters-Golden M. 1995. Cultured lung fibroblasts isolated from patients with idiopathic pulmonary fibrosis have a diminished capacity to synthesize prostaglandin E2 and to express cyclooxygenase-2. J Clin diminished capacity to
Invest $95: 1861-1868$.

Zaccolo M, Di Benedetto G, Lissandron V, Mancuso L. Terrin A, Zamparo I. 2006. Restricted diffusion of a freely diffusible second messenger: Mechanisms underlying compartmentalized CAMP signalling. Biochem Soc Trans 34:495-497.

Zhang Y, Lee TC, Guillemin B, Yu MC, Rom WN. 1993. Enhanced IL-I beta and tumor necrosis factor-alpha release and messenger RNA expression in macrophages from idiopathic pulmonary fibrosis or after asbestos exposure. J Immunol 150:4188-4196. 